\title{
Steel foam for structures: a review of applications, manufacturing and material properties
}

\author{
B.H. Smith ${ }^{\mathrm{a}}$, S. Szyniszewski ${ }^{\mathrm{b}}$, J.F. Hajjar ${ }^{\mathrm{c}}$, B.W. Schafer ${ }^{\mathrm{b} 1}$, S.R. Arwade ${ }^{\mathrm{a}}$ \\ ${ }^{a}$ Dept. of Civil \& Env. Engg. University of Massachusetts, Amherst, MA 01003 \\ ${ }^{\mathrm{b}}$ Dept. of Civil Engg., Johns Hopkins University, Baltimore, MD 21218 \\ ${ }^{c}$ Dept. of Civil \& Env. Engg., Northeastern University, Boston, MA 02115
}

\begin{abstract}
The objective of this paper is to provide a state-of-the-art review for the structural application, manufacturing, material properties, and modeling of a new material: steel foam. Foamed steel includes air voids in the material microstructure and as a result introduces density as a new design variable in steel material selection. By controlling density the engineering properties of steel components may be altered significantly: improvement in the weight-to-stiffness ratio is particularly pronounced, as is the available energy dissipation and thermal resistivity. Full-scale applications of steel foams in civil structures have not yet been demonstrated. Therefore, existing applications demonstrating either proof-of-concept for steel foam, or full-scale use of aluminum foams in situations with clear civil/structural analogs are highlighted. Adoption of steel foam relies on the manufacturing method, particularly its cost, and the resulting properties of the steel foam. Therefore, published methods for producing steel foam are summarized, along with measurements of steel foam structural (modulus, yield stress, etc.) and non-structural (thermal conductivity, acoustic absorption, etc.) properties. Finally, existing models for predicting foamed steel material properties are summarized to highlight the central role of material density. Taken in total the existing research demonstrates the viability of steel foams for use in civil/structural applications, while also pointing to areas where further research work is required.
\end{abstract}

\footnotetext{
${ }^{1}$ Corresponding author: 208 Latrobe Hall, 3400 N. Charles St., Johns Hopkins University, Baltimore, MD 21218. schafer@jhu.edu, 410.516.6265
} 


\section{Introduction}

The properties of structural steel have been largely invariant for well over 100 years. Altering the modulus of elasticity has proven to be nearly impossible, and even yield stress, which has seen increase in recent years has not changed as much as is commonly thought - the Eads Bridge in St. Louis, Missouri was designed and manufactured with $345 \mathrm{MPa}(50 \mathrm{ksi}$ ) yield stress steel in 1874. Civil engineering advances and the development of new, higher performance structural forms and components are strongly tied to the introduction of new materials. The introduction of iron, steel, reinforced and prestressed concrete each allowed engineers to achieve new extremes in span and height, and to decrease cost. Many of the material advances of the late $20^{\text {th }}$ and early $21^{\text {st }}$ century have not, however, propagated to civil engineering.

Metal foam materials present a unique opportunity for adoption in civil engineering applications. The base metals (aluminum, steel, etc.) are well understood and in many cases readily modeled with a high degree of accuracy. Foaming the metal, i.e. introducing voids in the microstructure, decreases the density $(\rho)$ and increases the apparent thickness. If designed with care, the resulting foamed component can have higher plate bending stiffness $\left(\propto E t^{3}\right)$ and weigh less than solid steel. In addition, the resulting component generally has a greatly increased energy dissipation capability and improved vibration, thermal, and acoustical properties. A steel engineer working with steel foam has a new degree of freedom: density $(\rho)$. The design space potentially covered by steel applications can grow immensely with density as a variable. Applications may at first be highly specialized, but as material production volume increases, and costs decrease, widespread adoption of steel foams becomes possible. 
Full-scale civil engineering applications for steel foam have not yet been demonstrated, so Section 2 describes applications of steel and aluminum foams in the mechanical, automotive, and aerospace domains that have clear analogs in civil engineering. Section 3 covers the most significant work to date, which has focused on developing manufacturing processes for steel foam. Commercial availability of aluminum foam at reasonable cost supports the potential industrialization of steel foam manufacturing. In Section 4, published measurements of the material properties (structural and non-structural) of steel foams are aggregated to show that the range of achievable properties is large and desirable. Section 5 explores models used to connect the material microstructure to the macroscopic material properties. Section 5 also covers the basics of steel foam plasticity modeling, necessary for advanced collapse analysis models of members and structures with steel foam components. Finally, research needs are identified in Section 6 and the paper ends, with conclusions, in Section 7.

\section{$2 \quad$ Potential Applications in Civil Engineering}

The ability to foam steel affords potential advantages (structural and non-structural) over solid steel that have been utilized in existing design applications:

\section{Structural advantages}

- Minimize weight

- Maximize stiffness (particularly bending)

- Increase energy dissipation

- Increase mechanical damping

- Tune vibration frequency

\section{Non-structural advantages}

- Decrease thermal conductivity

- Improve acoustical performance

- Provide air/fluid transport within material

- Electromagnetic and radiation shielding

- Joining thermally dissimilar materials

Compared to aluminum foams, for example, steel foam applications are at their beginning stage.

While fundamental advantages for using steel instead of aluminum as a base metal are clear (e.g., higher initial $E$ and $F_{y}$ ) manufacturing has been more challenging. Nevertheless, steel foam bars, 
rods, foam core sandwich plates, and foam filled tubes have been created and tested at laboratory scale (order $300 \mathrm{~mm}$ long and $50 \mathrm{~mm}$ diameter) [1]. The foundational work of [1] provides proof-of-concept for the manufacture of steel foam components similar to those used in existing aluminum foam applications. Existing aluminum foam applications have been summarized according to how the advantage of foaming has been exercised in the design application, with structural/mechanical advantages detailed in Table 1, and nonstructural advantages in Table 2.

\subsection{Structural Applications for metallic foams}

Example structural applications for metallic foams, utilizing benefits in weight, stiffness, energy dissipation, mechanical damping, and vibration frequency are summarized in Table 1. Existing applications are largely in the mechanical, aerospace, and automotive domains. For each application, therefore, the potential impact on civil engineering is also detailed in Table 1.

Steel foams exhibit excellent stiffness-to-weight ratios when loaded in flexure [7]. In particular, foam panels have higher bending stiffness than solid steel sheets of the same weight [2]. Therefore, the majority of existing structural applications seek to either minimize weight given stiffness constraints, or maximize stiffness given weight constraints (see Table 1). For example, a manufactured $16 \mathrm{~mm}$ sandwich panel (1 mm steel faces with $14 \mathrm{~mm}$ metal foam core) has comparable bending stiffness to a solid steel plate $10 \mathrm{~mm}$ thick, but at only $35 \%$ of the weight [4]. Further, a parking garage floor slab utilizing steel mesh reinforced metal foam floor slabs was proposed and full-scale load tests conducted [3] (see Table 1). The design met standard strength and serviceability requirements, including deflection and strength under localized loading, and the use of the metal foam sandwich panels reduced the weight of the floors by $75 \%$ in comparison to traditional reinforced concrete decks. 
Table 1 Example structural applications/advantages for metal foams
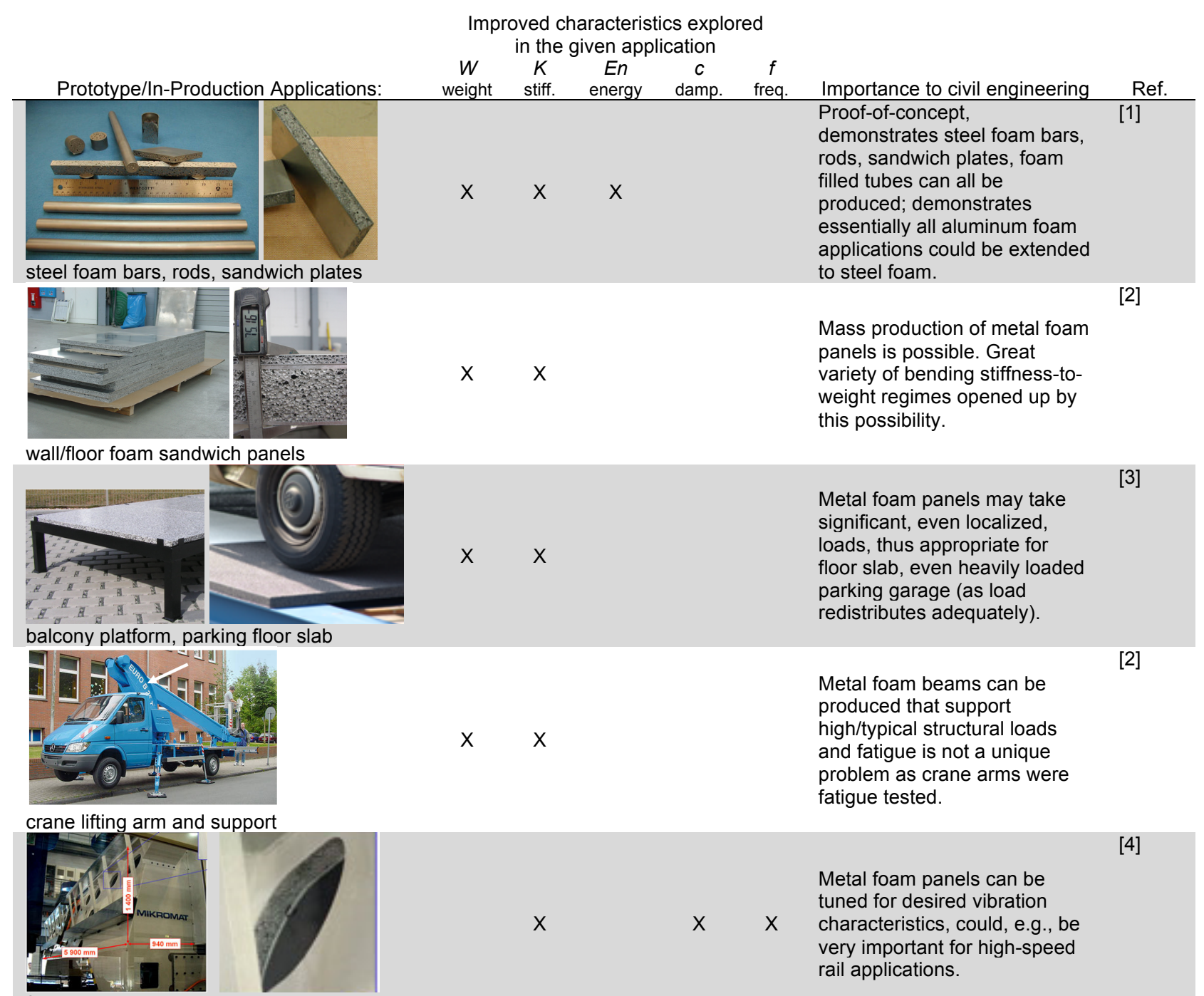

fabrication equipment

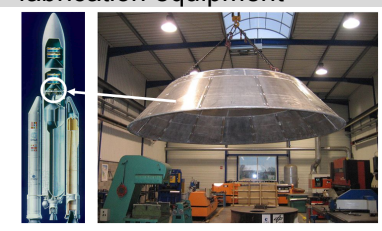

Shell structures possible with

[2] metal foams, tight dynamic performance constraints can be met. Metal foam explicitly cheaper than traditional sandwich panel in this case.

Ariane 5 rocket cone prototype

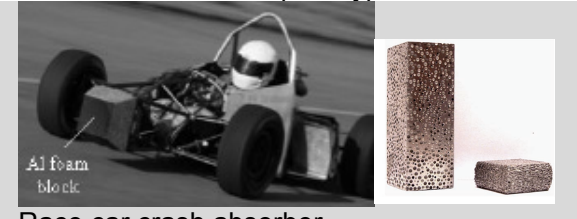

Kinetic energy dissipation is one of the main strengths of metal foams. Load transfer to the support limited by the foam yield. Slower deceleration reduces dynamic effects and

Race car crash absorber enhances driver's safety. 
Minimizing weight can have surprising benefits. The rigid body dynamics of a crane arm dictates that the mass of the arm controls the maximum lift. A crane arm with the same stiffness but less weight can lift more with the same ballast. With this basic principle in mind a metal foam lifting arm, weighing $50 \%$ less than its solid steel counterpart was created [2]. The crane is in production (60-100 units a year) and successfully underwent high cycle fatigue testing; thus demonstrating that heavily loaded beams under fatigue loading are possible with metal foams. Additional mechanical examples provided in Table 1 include improvements in fabrication equipment [4] and the cone of a prototype rocket [2] that explore the structural benefits of increasing mechanical damping, and tuning the vibration frequency of components.

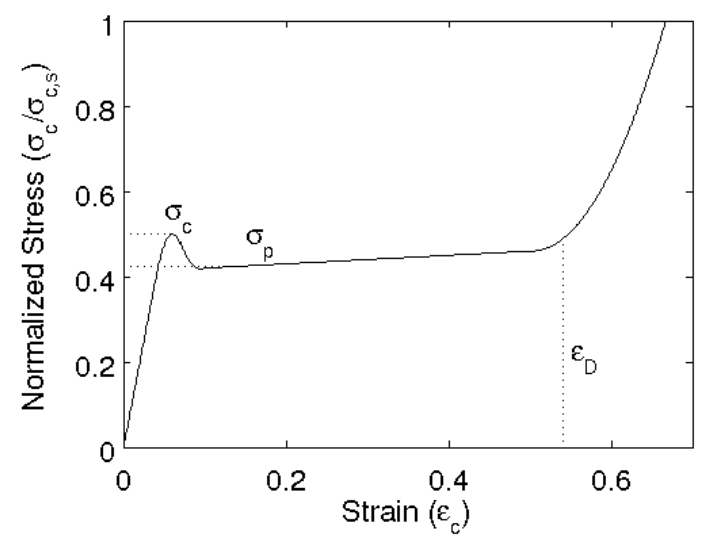

Figure 1: Typical stress-strain curve for metal foams in compression

In compression steel foams display a stress-strain curve similar to that of Figure 1, featuring an elastic region, a plateau region in which the voids begin plastic deformation, and a densification region in which cell walls come into contact with one another and compressive resistance rapidly increases. The potential for significant energy dissipation in compression is a target for many existing applications. Energy dissipation via large compressive deformations at low, constant stress levels have been used in the automotive industry for crash protection [5]. The yield stress of the foam is designed such that it does not substantially change the load carrying characteristics 
of the main car frame. Vehicles equipped with foamed elements decelerate over a longer distance and period of time thereby reducing accelerations experienced by the vehicle occupants [6]. The ability to absorb energy of impact or blast while limiting stress levels is crucial to the design of robust hardening systems for civil infrastructure.

An important structural advantage for metallic foams that has not been demonstrated to date is the mitigation of buckling both for rods and plates, and the conversion of limit states from unstable buckling modes with little to no energy dissipation to stable modes with crushing and/or post-buckling. In addition, applications with high strain rate low-cycle fatigue have not been explored. Existing structural advantages demonstrate the potential for steel foam in civil applications, but much work remains for these advantages to be realized in practice.

Table 2 Example non-structural applications/advantages for metal foams Improved characteristics explored in the given

\begin{tabular}{|c|c|c|c|c|c|c|c|}
\hline $\begin{array}{l}\text { Prototype/In-Production } \\
\text { Applications: }\end{array}$ & $\begin{array}{c}\alpha_{t} \\
\text { thermal }\end{array}$ & $\begin{array}{c}F \\
\text { fire }\end{array}$ & $\begin{array}{c}c_{L} \\
\text { acoustic }\end{array}$ & $\stackrel{q}{\text { transport }}$ & $\begin{array}{c}h \\
\text { shielding }\end{array}$ & Importance to civil engineering & Ref. \\
\hline $\begin{array}{l}\text { Industrial chill forms and } \\
\text { generic foamed parts }\end{array}$ & $\mathrm{X}$ & & & & & $\begin{array}{l}\text { Reduced thermal conductivity; } \\
\text { could help solve thermal } \\
\text { bridging problem in steel } \\
\text { applications. }\end{array}$ & {$[4,7]$} \\
\hline $\begin{array}{l}\text { Metal-ceramic heat shield } \\
\text { and biomedical implants }\end{array}$ & $\mathrm{X}$ & & & & & $\begin{array}{l}\text { Metal foams allow materials of } \\
\text { disparate thermal expansion to } \\
\text { be joined to great benefit. }\end{array}$ & {$[8,9,10]$} \\
\hline Fire retarders & $\mathrm{X}$ & $X$ & & & & $\begin{array}{l}\text { Potential for integral fire } \\
\text { resistance in steel members. } \\
\text { Modeling tools advanced in } \\
\text { this application. }\end{array}$ & {$[11,12]$} \\
\hline Heat exchanger & $\mathrm{X}$ & & & $X$ & & $\begin{array}{l}\text { Open cell metal foams allow } \\
\text { fluid transport, potential } \\
\text { application for wall to be } \\
\text { integrated with HVAC. }\end{array}$ & {$[7,8]$} \\
\hline $\begin{array}{l}\text { Sound absorber on bridge, } \\
\text { in auto exhaust, and } \\
\text { general use }\end{array}$ & & & $\mathrm{X}$ & & & $\begin{array}{l}\text { Potential to integrate sound } \\
\text { absorption and vibration } \\
\text { frequency control into } \\
\text { bridge/rail design. }\end{array}$ & {$[7,13,14]$} \\
\hline $\begin{array}{l}\text { Electromagnetic shield and } \\
\text { radiation shield }\end{array}$ & & & & & $\mathrm{X}$ & $\begin{array}{l}\text { Potential infrastructure } \\
\text { applications for shielding } \\
\text { buried structures, components } \\
\text { of critical facilities, ... }\end{array}$ & {$[15,16]$} \\
\hline
\end{tabular}

\subsection{Non-Structural Applications for metallic foams}

Example non-structural applications for metallic foams, utilizing benefits in thermal conductivity, fire retardance, acoustics, air and fluid transport, and/or shielding are summarized 
in Table 2. Existing applications are largely in the mechanical engineering domain; therefore, for each application the potential importance to civil engineering is also discussed in Table 2 . The potential for multifunctional steel foam components (e.g., wall and/or roof panels that have superior structural and energy performance) is clear, as is the fact that much work remains.

\section{Steel Foam Manufacturing Processes}

While the previous section has introduced the classes of civil engineering applications in which steel foam can be expected to have potential impact, the novelty of steel foam as an engineering material, and the unusual, highly porous, microstructure makes knowledge of the manufacturing process essential. Significant research has been performed regarding optimal manufacturing methods for foams made of metals, such as aluminum, titanium and copper, but steel presents unusual challenges, including steel's high melting point, that require new technology.

Current methods of steel foam manufacture may create open-celled (permeable voids) or closedcell (sealed voids) foams with varying regularity, isotropy, and density. Published methods for producing steel foams are summarized in Table 3. Three manufacturing methods are emphasized here: powder metallurgy (Section 3.1) because it has already been used successfully to create structural scale steel foam prototypes in [1], hollow spheres (Section 3.2) because this method is in active commercial production, and Lotus-type (Section 3.3) because this method has high potential for continuous casting processes necessary for low cost steel foam production.

\subsection{Powder metallurgy}

Originally developed for aluminum foams, the powder metallurgy method was one of the first methods to be applied to steel foams and is still one of the two most popular [1]. It produces primarily closed-cell foams and is capable of developing highly anisotropic cell morphologies. 
The relative densities possible with this method are among the highest, up to 0.65 , making it a strong candidate for structural engineering applications that demand that the foam retain a relatively high portion of the base material strength. The powder metallurgy method involves combining metal powders [17] with a foaming agent $[17,18,19,20]$, compacting the resulting mixture, and then sintering the compacted blank at pressures of 900-1000 MPa [17]. The metal is brought to the melting point and held there for a period of time depending on the foaming agent and desired cell morphology, usually about 15 minutes [17]. The final product may also be heat treated to optimize the crystal structure of the base metal. A variation, known as the powder space holder method, involves using a simple filler material rather than the foaming agent and allows for graded porosity across the material [21].

\subsection{Hollow spheres}

Giving highly predictable mechanical properties and requiring only minimal heat treatment, the hollow spheres method is the second of the two most currently popular techniques for manufacturing steel foams [22]. Depending on sphere geometry closed-cell or mixed open- and closed-cell morphologies are possible, with relative densities from about $4 \%$ to $20 \%$ possible. The method produces highly predictable material properties as cell (void) size is strictly controlled [23]. Hollow sphere processes involve taking pre-manufactured hollow spheres of metal and consolidating them using an adhesive matrix, casting in a metal matrix [24], compacting through powder metallurgy techniques [25], or sintering the spheres [26]. One special variation involves manufacturing the spheres with a blowing agent within and then allowing the spheres to expand and sinter into the resultant shapes [27]. 
Table 3: Table of known manufacturing methods for steel foams and their basic characteristics

\begin{tabular}{|c|c|c|c|c|c|c|c|c|c|}
\hline & & & & Manufac & uring Proc & esses for Steel Foam & & & \\
\hline Process & $\begin{array}{c}\text { Micro- } \\
\text { structure }\end{array}$ & Primary Variables & $\begin{array}{l}\text { Min } \\
\text { Density }\end{array}$ & $\begin{array}{l}\text { Max } \\
\text { Density }\end{array}$ & $\begin{array}{l}\text { Cell } \\
\text { Morph. }\end{array}$ & Morphology Notes & Major Advantages & Major Disadvantages & Ref. \\
\hline $\begin{array}{l}\text { Powder } \\
7 \\
\text { metallurgical }\end{array}$ & mon & $\begin{array}{l}\text { Foaming agents } \\
\text { (e.g. } \mathrm{MgCO}_{3}, \\
\left.\mathrm{CaCO}_{3}, \mathrm{SrCO}_{3}\right) \\
\text { cooling patterns }\end{array}$ & 0.04 & 0.65 & Closed & $\begin{array}{l}\text { Anisotropic if not } \\
\text { annealed for long } \\
\text { enough, or with some } \\
\text { mixing methods }\end{array}$ & $\begin{array}{l}\text { High relative densities } \\
\text { possible }\end{array}$ & & {$[18,28]$} \\
\hline $\begin{array}{l}\text { Injection } \\
\text { molding with } \\
\text { glass balls }\end{array}$ & 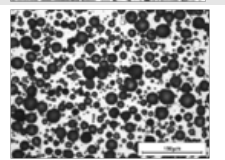 & $\begin{array}{l}\text { Types of glass } \\
\text { (e.g. IM30K, } \\
\text { S60HS) }\end{array}$ & 0.48 & 0.66 & Closed & $\begin{array}{l}\text { Glass holds shape of } \\
\text { voids, and increases } \\
\text { brittleness of material }\end{array}$ & $\begin{array}{l}\text { High relative densities } \\
\text { possible }\end{array}$ & $\begin{array}{l}\text { Potential chemical } \\
\text { reactions with glass; } \\
\text { some glass can break } \\
\text { in forming process }\end{array}$ & [34] \\
\hline $\begin{array}{l}\text { Oxide ceramic } \\
\text { foam precursor }\end{array}$ & & $\begin{array}{l}\text { Ceramic / cement } \\
\text { precursor } \\
\text { materials }\end{array}$ & 0.13 & 0.23 & Open & $\begin{array}{l}\text { Polygonal shapes on } \\
\text { small scales, residues } \\
\text { of reactions remain }\end{array}$ & $\begin{array}{l}\text { Foaming at room } \\
\text { temperatures; complex } \\
\text { shapes possible; standard } \\
\text { equipment }\end{array}$ & & {$[30,31]$} \\
\hline $\begin{array}{l}\text { Consolidation } \\
\text { of hollow } \\
\text { spheres }\end{array}$ & ond & $\begin{array}{l}\text { Sphere } \\
\text { manufacture, } \\
\text { sphere } \\
\text { connections }\end{array}$ & 0.04 & 0.21 & Either & $\begin{array}{l}\text { Two different cell } \\
\text { voids: interior of the } \\
\text { spheres, and spaces } \\
\text { between spheres }\end{array}$ & $\begin{array}{l}\text { Very low relative densities } \\
\text { possible; highly predictable } \\
\text { and consistent behavior }\end{array}$ & $\begin{array}{l}\text { High relative densities } \\
\text { not possible }\end{array}$ & $\begin{array}{l}{[30,23,} \\
22,25]\end{array}$ \\
\hline $\begin{array}{l}\text { Working and } \\
\text { sintering of } \\
\text { bimaterial rods }\end{array}$ & & $\begin{array}{l}\text { Types of working } \\
\text { before sintering, } \\
\text { filler materials }\end{array}$ & 0.05 & 0.95 & Open & $\begin{array}{l}\text { Anisotropy is } \\
\text { controllable }\end{array}$ & $\begin{array}{l}\text { Wide range of relative } \\
\text { densities possible; } \\
\text { anisotropies are } \\
\text { controllable }\end{array}$ & & [35] \\
\hline $\begin{array}{l}\text { Composite PM } \\
\text { / hollow } \\
\text { spheres }\end{array}$ & & $\begin{array}{l}\text { Matrix material } \\
\text { used, casting may } \\
\text { be done instead of } \\
\text { PM }\end{array}$ & 0.32 & 0.43 & Closed & $\begin{array}{l}\text { Powder metallurgical } \\
\text { region may be foamed } \\
\text { or a semi-solid matrix }\end{array}$ & $\begin{array}{l}\text { Behavior is both } \\
\text { predictable and strong; no } \\
\text { collapse bands until } \\
\text { densification }\end{array}$ & & {$[22,25]$} \\
\hline $\begin{array}{l}\text { Slip Reaction } \\
\text { Foam Sintering }\end{array}$ & & $\begin{array}{l}\text { Dispersant, } \\
\text { bubbling agent, } \\
\text { and relative } \\
\text { quantities }\end{array}$ & 0.12 & 0.41 & Open & $\begin{array}{l}\text { Highly variable cell } \\
\text { diameters are } \\
\text { produced }\end{array}$ & $\begin{array}{l}\text { Many optimizable } \\
\text { manufacturing parameters; } \\
\text { foaming at room temp. }\end{array}$ & & [32] \\
\hline $\begin{array}{l}\text { Polymer foam } \\
\text { precursor }\end{array}$ & & $\begin{array}{l}\text { Polymer material } \\
\text { used }\end{array}$ & 0.04 & 0.11 & Open & $\begin{array}{l}\text { Cells take on } \\
\text { whatever } \\
\text { characteristics the } \\
\text { polymer foam had }\end{array}$ & $\begin{array}{l}\text { Low density open-cell } \\
\text { structure for filter and } \\
\text { sound absorption } \\
\text { applications }\end{array}$ & $\begin{array}{l}\text { Too weak for most } \\
\text { structural applications }\end{array}$ & [32] \\
\hline $\begin{array}{l}\text { Powder space } \\
\text { holder }\end{array}$ & 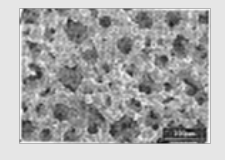 & $\begin{array}{l}\text { Filler material } \\
\text { used, shapes and } \\
\text { gradation of } \\
\text { material }\end{array}$ & 0.35 & 0.95 & Closed & $\begin{array}{l}\text { Porosity may be } \\
\text { graded across } \\
\text { material }\end{array}$ & $\begin{array}{l}\text { Porosity may be graded } \\
\text { across a wide range across } \\
\text { the material }\end{array}$ & & [21] \\
\hline $\begin{array}{l}\text { Lotus-type / } \\
\text { gasar }\end{array}$ & sude & $\begin{array}{l}\text { Partial pressure of } \\
\text { gas, which gas to } \\
\text { use }\end{array}$ & 0.36 & 1.00 & Closed & $\begin{array}{l}\text { Highly anisotropic but } \\
\text { aligned cell shapes } \\
\text { are unavoidable }\end{array}$ & $\begin{array}{l}\text { Manufacturing by } \\
\text { continuous production } \\
\text { techniques; high relative } \\
\text { densities are possible }\end{array}$ & $\begin{array}{l}\text { Isotropic cell } \\
\text { morphologies are not } \\
\text { possible }\end{array}$ & {$[28,29]$} \\
\hline
\end{tabular}




\subsection{Lotus-type}

The lotus-type manufacturing method, also known as the gasar method, is capable of producing high-density foams, ranging from about $35 \%$ to $100 \%$ relative density with highly anisotropic, closed-cell morphology. The lotus-type method features the great advantage that it is readily adapted to a continuous casting process [28]. The method also allows for high tensile strength and ductility — up to $190 \mathrm{MPa}$ at over 30\% strain for a foam of 50\% relative density. Lotus-type steel foams take advantage of the fact that many gases are more soluble in metals while they are in their liquid state than when they are in their solid state. In the case of steel, either hydrogen or a hydrogen-helium mixture is diffused into molten steel [29]. As the steel solidifies, the gas leaves solution, creating pores within the solid steel body. Two similar methods of performing this process continuously have been developed: continuous zone melting and continuous casting [28]. In continuous zone melting, one segment of a rod of the base metal is melted in the presence of the diffusive gas, and then allowed to re-solidify shortly thereafter. In continuous casting, the base metal is kept melted in a crucible in the presence of the gas, and then slowly drained and solidified [28].

\subsection{Other Methods}

As Table 3 shows numerous other methods exist for steel foam manufacture. For instance, ceramic [30,31] or polymer [32] precursors may be used to establish the voids. The final steel foam will take on the same morphology as the precursor material and relative densities ranging from $4 \%$ to $23 \%$, depending largely on the precursor, have been realized. Slip reaction foam sintering, a method specific to iron-based foams, has also been used successfully in manufacture and produces foams of moderate densities, ranging from about $12 \%$ to $41 \%[1,33]$. 
There are several further methods of steel foam manufacture that have been the subject of at least preliminary investigation by material scientists, including injection molding [34] bimaterial rods [35], and fibrous foams including truss cores, and sintered fibers. Truss cores involve twisting or welding thin fibers into mesoscale trusses of various shapes [36] while fiber sintering involves laying out fibers and sintering them together [37]. These fibrous foams have low strength, but may work productively as core material in sandwich panels.

\section{$4 \quad$ Macroscopic Properties}

For engineers, the material manufacturing process is in essence incidental to the material properties that are achieved by that manufacturing process. For the manufacturing processes described in Section 3 limited tests of the mechanical properties of the resulting steel foams have been performed and are summarized in Table 4 . The extent of available results varies greatly between manufacturing methods. Powder metallurgy and hollow sphere foams have by far the most results in the published literature. Other manufacturing methods are typically limited to only a single research group.

\subsection{Experimentally measured structural properties}

Experimentally measured structural properties are summarized in Table 4. It is implicitly assumed throughout the literature that foams of a given base material and relative density will behave the same [38]; however, as Table 4 highlights the material properties depend upon the manufacturing method [39], cell size and morphology [40], and sample size tested [41]. For example, the lotus-type steel foams have anisotropic voids, resulting in tensile and compressive strengths which vary by as much as a factor of two depending on direction [18,42]. 
Table 4: Table of material properties as extracted from selected publications.

Material Properties of Steel Foam

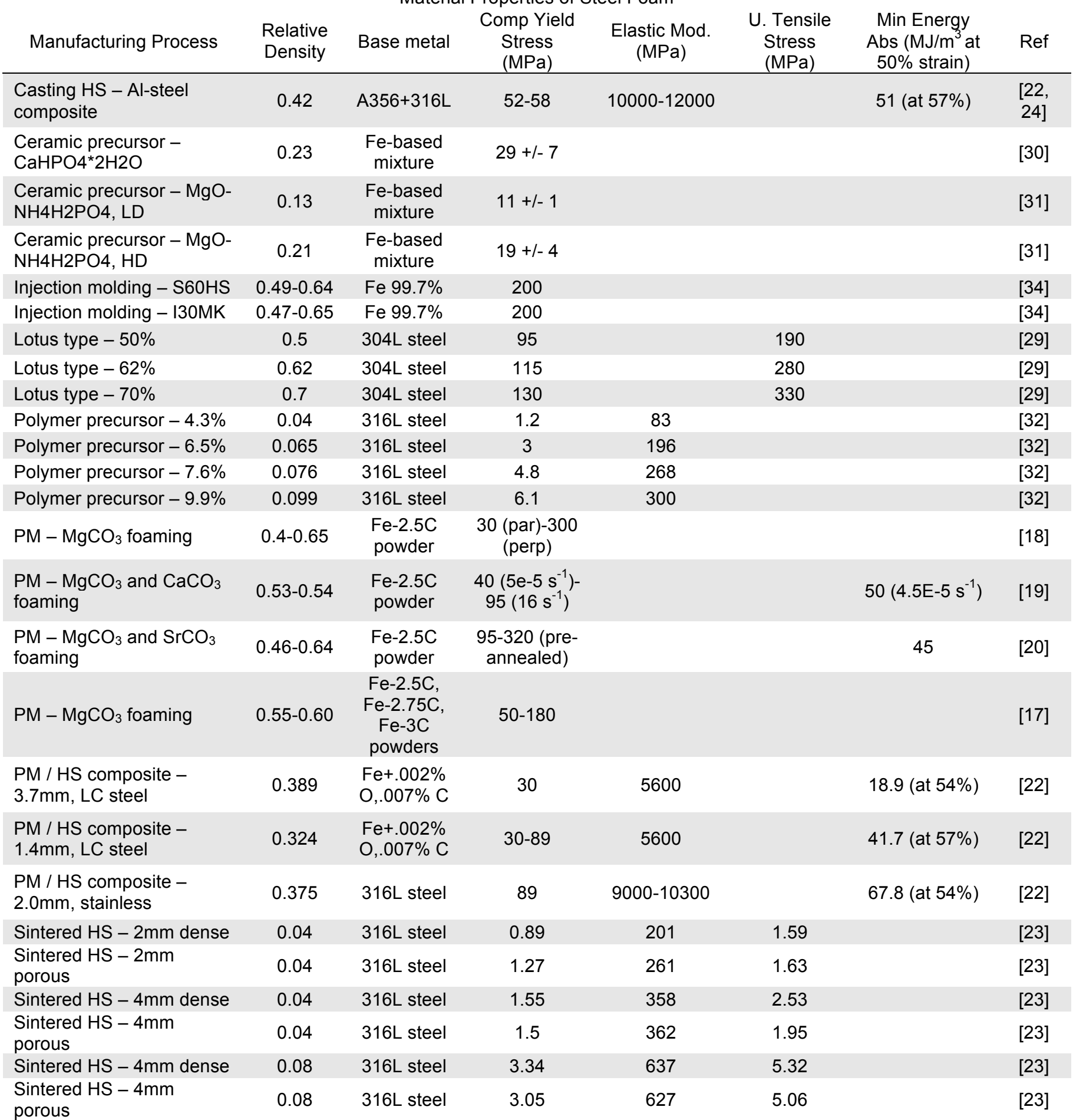

The most common measured mechanical property is the compressive yield strength or plateau strength (Figure 1). The plateau strength is usually about 5\% higher than the measured yield strength [38]. As shown in Table 4, the compressive yield strength of steel foam varies from 


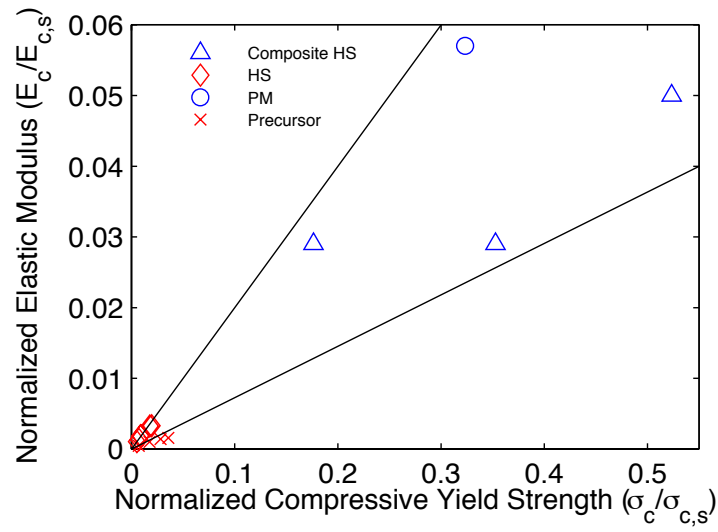

approximately $1 \mathrm{MPa}$ for highly porous foams ( $<5 \%$ density) to $300 \mathrm{MPa}$ for dense samples. At about 50\% density, steel foam's compressive strength varies from $100 \mathrm{MPa}$ for typical samples to upwards of $300 \mathrm{MPa}$ for highly anisotropic or specially heat-treated samples. Compressive yield strength $\left(\sigma_{\mathrm{c}}\right)$ normalized by the solid steel compressive yield $\left(\sigma_{\mathrm{c}, \mathrm{s}}\right)$ is plotted against elastic modulus $\left(\mathrm{E}_{\mathrm{c}}\right)$ normalized by the solid steel elastic modulus $\left(\mathrm{E}_{\mathrm{c}, \mathrm{s}}\right)$ in Figure 2, and indicates that a wide range of stiffness to strength ratios have been achieved with steel foams, again illustrating the large material selection space available to designers.

Figures $2 \mathrm{a}$ and $2 \mathrm{~b}$ : Compressive yield strength versus normalized elastic modulus of various types of steel foams. Gibson \& Ashby's minimum and maximum values [38] are plotted as solid lines (see Section 5).

Other mechanical properties: elastic modulus, Poisson's ratio, ultimate tensile strength, densification strain, and energy absorption have been less frequently published. Measured elastic modulus values are reported in Table 4 and vary from 200 to $12,000 \mathrm{MPa}$, but measured values for lotus-type foams and other steel foams expected to have high modulus are not available. Poisson's ratio for steel foams is commonly assumed to be the elastic base metal value of 0.3 ; however, for hollow sphere steel foams experiments report ranges from 0 (or even slightly negative) to 0.4 [43] and 0.09 to 0.2 [37] depending on the density and manufacturing method.

Evaluation of the densification strain and energy absorption is possible in most experiments, but few values are published. Densification usually occurs at $55-70 \%$ strain and measured energy 
absorption up to $50 \%$ strain, range from $40 \mathrm{MJ} / \mathrm{m}^{3}$ to $100 \mathrm{MJ} / \mathrm{m}^{3}$, for densities near $50 \%$ $[19,20,22]$. In the few tension tests conducted tensile strengths range from $1 \mathrm{MPa}$ for low-density sintered hollow spheres foams, up to and over $300 \mathrm{MPa}$ for the anisotropic lotus-type foam parallel to the pore orientation $[20,23]$.

\subsection{Testing procedures}

Experimentally measured steel foam material properties exhibit significant variability across manufacturing methods, research groups, and even within nominally identical specimens [43]. Bias in the data exists because of strong correlation between manufacturing type and research group, for example only two research teams work on lotus-type manufacturing $[47,48]$. Variability is also due to the lack of standardization in testing. The material science focused research to date does not emphasize, nor in many cases explain, the details of testing performed. Further, as Table 6 summarizes standardized testing methods are not yet available.

Table 6: Table of comparable American and international testing standards for metal foams

\begin{tabular}{ccc}
\hline Test & Similar Standards & Standard Is Designed For \\
\hline Cell openness & ISO 2738 & Metal foams \\
Linear dimensions & ISO 4590, ASTM D6226 & Cellular plastics \\
Density & ISO 1923 & Cellular plastics \\
& ISO 2738 & Metal foams \\
& ISO 845, ASTM D1622 & Cellular plastics \\
Cell size & ASTM C271 & Sandwich foam core \\
& ISO 24003 & Metal foams \\
Compression & ASTM D3576 & Cellular plastics \\
& ISO/DIS 13314(E), DIN & Metal foams \\
Tension & 50134, JIS H7902 & Cellular plastics \\
& ISO 844, ASTM D1621 & Cellular plastics \\
Shear & ISO 1926, ASTM D1623 & Honeycomb ceramics \\
Shear fatigue & ASTM C1674 & Sandwich foam core \\
Compressive creep & ASTM C273, DIN 53295 & Cellular plastics \\
Bending & ISO 1922 & Sandwich foam core \\
Elastic modulus & ASTM C394 & Cellular plastics \\
Poisson's ratio & ISO 1209-1 & Cellular plastics \\
\hline & ISO 1209-2 & Cellular plastics \\
\hline & ASTM D6790 & Honeycomb core materials
\end{tabular}


Recently, there has been some effort to begin standardizing testing of metal foams. Japanese and German [49] standards for compression testing of metal foams have been accepted, and the International Standards Organization (ISO) recently combined these two standards into its own international standard for compression testing of metal foams (ISO/DIS 13314, still in draft state as of this writing). However, there are no standards that currently exist for tensile, shear, cyclic, or other mechanical tests on metal foams. There are analogues in testing of cellular plastics and ceramics, as listed in Table 6, or in certain testing procedures for solid metals, but metal foam testing procedures must be devised by analogy to these standards.

\subsection{Homogenized models for property determination}

The first and still most widely accepted models for representing the mechanics of metal foams are those developed by Gibson and Ashby $[38,62]$ as summarized in Table 8 . The expressions assume that the primary dependent variable for all foam mechanics is the relative density of the foam, all other effects are lumped into a multiplicative coefficient with typical ranges provided in Table 8. Selection of the appropriate coefficient must be done with care and the resulting expressions are only valid for a small range of relative densities and are morphology/manufacturing dependent. Convergence to solid steel values at high relative density is not intrinsic to the expressions.

Table 8: Equations for mechanical properties of metal foams as set by Gibson and Ashby [38]

\begin{tabular}{ccc} 
Property & Open-Cell Foam & Closed-Cell Foam \\
\hline Elastic modulus & $\mathrm{E} / \mathrm{E}_{\mathrm{S}}=(0.1-4) \cdot\left(\rho / \rho_{\mathrm{s}}\right)^{2}$ & $\mathrm{E} / \mathrm{E}_{\mathrm{s}}=(0.1-1.0) \cdot\left[0.5 \cdot\left(\rho / \rho_{\mathrm{s}}\right)^{2}+0.3 \cdot\left(\rho / \rho_{\mathrm{s}}\right)\right]$ \\
Compressive yield strength & $\sigma_{\mathrm{c}} / \sigma_{\mathrm{c}, \mathrm{s}}=(0.1-1.0) \cdot\left(\rho / \rho_{\mathrm{s}}\right)^{3 / 2}$ & $\sigma_{\mathrm{c}} / \sigma_{\mathrm{c}, \mathrm{s}}=(0.1-1.0) \cdot\left[0.5 \cdot\left(\rho / \rho_{\mathrm{s}}\right)^{2 / 3}+0.3 \cdot\left(\rho / \rho_{\mathrm{s}}\right)\right]$ \\
Tensile strength & $\sigma_{\mathrm{t}}=(1.1-1.4) \cdot \sigma_{\mathrm{c}}$ & $\sigma_{\mathrm{t}}=(1.1-1.4) \cdot \sigma_{\mathrm{c}}$ \\
Shear modulus & $\mathrm{G}=3 / 8 \cdot \mathrm{E}$ & $\mathrm{G}=3 / 8 \cdot \mathrm{E}$ \\
Densification strain & $\varepsilon_{\mathrm{D}}=(0.9-1.0) \cdot\left[1-1.4 \cdot\left(\rho / \rho_{\mathrm{s}}\right)+0.4 \cdot\left(\rho / \rho_{\mathrm{s}}\right)^{3}\right]$ & $\varepsilon_{\mathrm{D}}=(0.9-1.0) \cdot\left[1-1.4 \cdot\left(\rho / \rho_{\mathrm{s}}\right)+0.4 \cdot\left(\rho / \rho_{\mathrm{s}}\right)^{3}\right]$
\end{tabular}



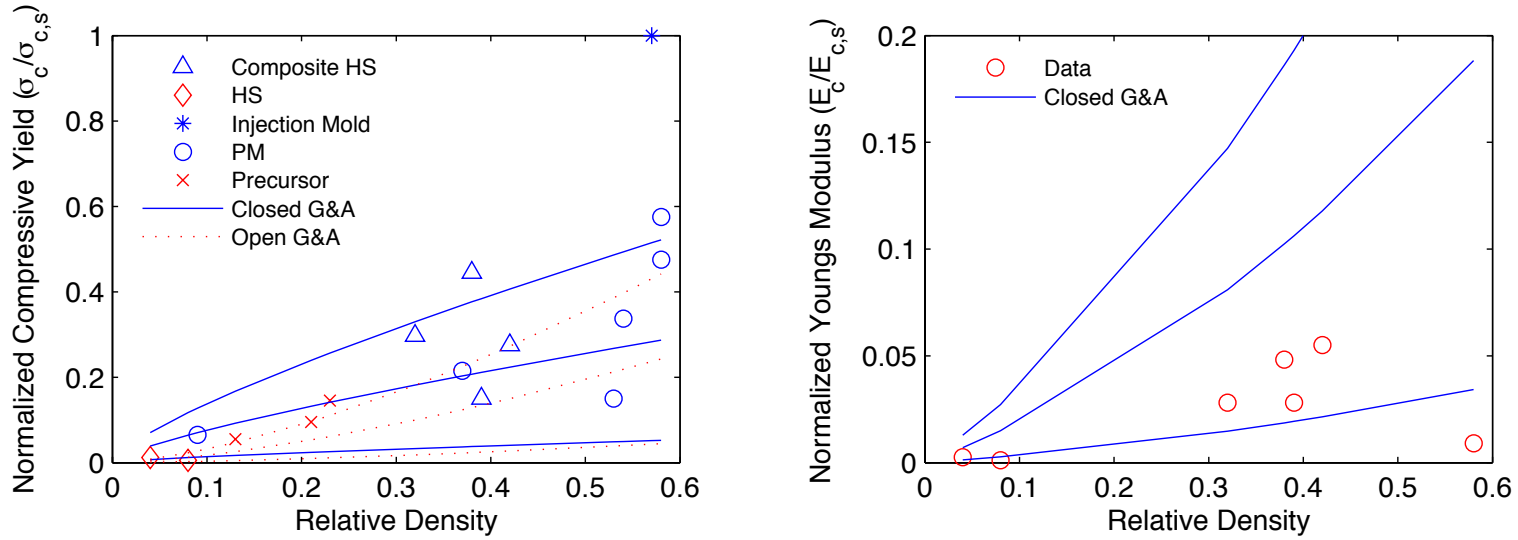

Figure 3: Comparison of available experimental data with Gibson and Ashby expressions of Table 8. Blue lines indicate Gibson \& Ashby expressions with leading coefficients equal to minimum, maximum, and middle value.

Experimental researchers have also developed application specific versions of the Gibson and Ashby expressions $[38,63,64,65]$. Comparison of these expressions with those of Gibson and Ashby demonstrate that although all yield different solutions, they remain within the established bounds of Gibson and Ashby.

\subsection{Computational models}

Explicit modeling of the steel foam microstructure has been completed by a variety of investigators as summarized in Table 7. While nearly all of the studies include plasticity in the simulation, only 5 include contact, and none include material fracture; implying that simulation of the densification strain and tensile ductility is an underdeveloped area of inquiry. A number of 
microstructural features are present in manufactured foams, but have not yet been modeled: strain hardening in the base metal, the presence of pressure in internal voids, and voids made from glass or other materials.

Table 7: Computational microstructural modeling approaches for metal foams

\begin{tabular}{|c|c|c|c|}
\hline Microstructure Representation & Nonlinearities Included & Behaviors Modeled & Ref. \\
\hline $\begin{array}{l}\text { FCC hollow spheres, simulated } \\
\text { weld connections }\end{array}$ & None - elastic only & 3 imposed stress tensors & [52] \\
\hline $\begin{array}{l}\text { Two 2D circles with weld } \\
\text { connections }\end{array}$ & $\begin{array}{l}\text { Power law strain } \\
\text { hardening, contact }\end{array}$ & $\begin{array}{l}\text { Damage and } \\
\text { densification of spheres }\end{array}$ & [53] \\
\hline $\begin{array}{l}\text { SC hollow spheres, simulated } \\
\text { weld connections }\end{array}$ & $\begin{array}{l}\text { Some power law strain } \\
\text { hard. }\end{array}$ & $\begin{array}{l}40 \text { imposed stress } \\
\text { tensors }\end{array}$ & [54] \\
\hline $\begin{array}{l}\text { Tetrakaidecahedrons tightly- } \\
\text { packed (open cell) }\end{array}$ & Plastic deformation & $\begin{array}{l}\text { Elastic compression and } \\
\text { plastic damage }\end{array}$ & {$[50]$} \\
\hline $\begin{array}{l}\text { FCC and HCP hollow spheres, } \\
\text { direct contact }\end{array}$ & $\begin{array}{l}\text { Contact, plastic } \\
\text { deformation }\end{array}$ & $\begin{array}{l}\text { Plastic response in } \\
\text { compression and tension }\end{array}$ & [55] \\
\hline $\begin{array}{l}\text { Tetrakaidecahedrons } \mathrm{w} / \text { random } \\
\text { defects }\end{array}$ & $\begin{array}{l}\text { Large displacements, } \\
\text { plastic deformation }\end{array}$ & $\begin{array}{l}\text { Plastic collapse in } \\
\text { uniaxial compression }\end{array}$ & {$[51]$} \\
\hline $\begin{array}{l}\text { SC, BCC, FCC, and HCP hollow } \\
\text { spheres }\end{array}$ & Plastic deformation & $\begin{array}{l}\text { Heat transfer, uniaxial } \\
\text { tension }\end{array}$ & [56] \\
\hline SC hollow spheres & $\begin{array}{l}\text { Non-penetration contact, } \\
\text { plastic deformation }\end{array}$ & $\begin{array}{l}\text { Plastic collapse in } \\
\text { uniaxial compression }\end{array}$ & [57] \\
\hline $\begin{array}{l}\text { Composite material with random } \\
\text { hollow spheres }\end{array}$ & Plastic deformation & Uniaxial compression & [58] \\
\hline FCC hollow spheres & $\begin{array}{l}\text { Contact, plastic } \\
\text { deformation }\end{array}$ & $\begin{array}{l}\text { Plastic collapse in } \\
\text { uniaxial compression }\end{array}$ & [59] \\
\hline ABC symmetry hollow spheres & Plastic deformation & Uniaxial compression & [60] \\
\hline $\begin{array}{l}\text { SC, BCC, FCC, and HCP hollow } \\
\text { spheres }\end{array}$ & Plastic deformation & Uniaxial compression & [61] \\
\hline Random hollow spheres & $\begin{array}{l}\text { Non-penetration contact, } \\
\text { plastic deformation }\end{array}$ & Uniaxial compression & [43] \\
\hline
\end{tabular}

Continuum constitutive models of metallic foams have also been developed [67],[68], improved and validated for aluminum foams [69,70], and are available in commercial finite element software such as LS-DYNA and ABAQUS. Key features of the developed models are pressure dependence in the plastic regime, nonlinear strain hardening, and tensile fracture. Calibration and validation to steel foams has not been completed for these models. 


\subsection{Experimentally measured non-structural properties}

A basic summary of tested thermal, acoustic, and permeability properties is provided in Table 5 . Non-structural properties are directly associated with parameters other than relative density: cell morphology for permeability [44], cell size for acoustic absorption [45], and cell wall thickness for thermal conductivity [46]. Nevertheless, the primary predictive parameter is still assumed to be relative density, and Table 5 is categorized based on the relative density at which the nonstructural properties are measured.

Table 5: Table of non-mechanical material properties for steel foam, including thermal, acoustic, and permeability.

\begin{tabular}{|c|c|c|c|c|c|}
\hline Property & Minimum & (a) Density & Maximum & @Density & Ref. \\
\hline Thermal Conductivity $^{\mathrm{a}}(\mathrm{W} / \mathrm{mK})$ & 0.2 & 0.05 & 1.2 & 0.1 & {$[46]$} \\
\hline Acoustic Absorption Coeff @ 500 Hz & 0.05 & 0.12 & 0.6 & 0.2 & {$[45]$} \\
\hline Acoustic Absorption Coeff @ $5000 \mathrm{~Hz}$ & 0.6 & 0.27 & 0.99 & 0.12 & {$[4$} \\
\hline Permeability $\left(\mathrm{m}^{2} * 10^{-9}\right)$ & 2 & 0.14 & 28 & 0.1 & \\
\hline Drag Coefficient $\left(\mathrm{s}^{2} / \mathrm{m} * 10^{3}\right)$ & 0.3 & 0.9 & 2.2 & 0.14 & \\
\hline
\end{tabular}

a) solid steel thermal conductivity in the range of $20-50 \mathrm{~W} / \mathrm{mK}$

\section{$5 \quad$ Research Needs}

Existing research demonstrates the viability of steel foam and provides insights on the enormous potential of the material. However, important gaps exist in current work, gaps that are impediments to increased adoption and demand for steel foams.

Experimental, analytical, and computational exploration of the regime of high relative density foams, a regime that provides improved structural and non-structural properties with the least reduction in effective strength and modulus is needed. A number of steel foam mechanical properties have not seen sufficient study, including tensile response and low-cycle fatigue, which have seen little to no study, and densification strain ultimate stress, and Poisson's ratio which have seen limited study but not in a manner conducive to generalization, nor in sufficient detail. Material testing standards are needed to facilitate sharing of the data and to move the industry towards common goals, and more clearly stated performance. Joinery of steel foams, both by 
mechanical fasteners and welding, needs further study. Computational microstructural models show great promise for not only better understanding the behavior, but also for extending experimental results for homogenization and calibration of continuum plasticity models. Microstructural models incorporating uncertainty, more realistic void structures, contact, and fracture are needed. Calibration of continuum plasticity models for a manufacturable steel foam is needed. Model-based demonstration projects that quantify the benefit of steel foams in specific civil engineering design scenarios are needed. Essentially, demonstration candidates for each of the structural and non-structural advantages: from weight and stiffness to thermal and acoustic need to be completed. Excellent candidates include increased energy absorption through mitigating buckling in members, lightweight multi-functional (stiffness, energy, thermal, acoustic) wall and floor panels, energy dissipation fuses for seismic design, vibration tuned girders for high-speed rail, and other applications. Physical, structural scale demonstration models of steel foam are needed, as are examples of joinery methods: welding, bolting, etc. Beyond laboratory scale bars and plates, structural scale members, walls, and floors need to be

produced, tested, and used in actual civil engineering applications. Concomitant with this effort model standards are needed for steel foam so that the material may be adopted and used in civil engineering design.

\section{Conclusions}

Existing applications of metal foams show that members, panels, and shells all may be produced and used in civil engineering applications. Examples of panels (balcony, parking garage slab) and members (crane arm) demonstrate that typical civil/structural demands, including strength, serviceability, and fatigue, can be met by metal foams; and these demands can be met while also 
minimizing weight, and potentially increasing energy absorption, as well as a host of nonstructural properties.

The manufacture of steel foam is now mature in the laboratory setting and is awaiting the proper impetus for commercialization. Several methods of manufacture have been developed, with powder metallurgy, hollow sphere, and lotus-type proving the most popular and each holding certain unique advantages. Relative densities from $4 \%$ continuously through to $100 \%$ have been achieved in both open- and closed-cell foams, some with anisotropic or otherwise unique cell morphologies. Some methods have even demonstrated industrial-scale manufacturing potential through continuous production processes.

Material properties of steel foams have shown unique promise in their high energy absorption, large range of possible strength to elastic modulus ratios, and high ductility in certain types of steel foam. These structural properties may potentially be combined with non-structural advantages, such as steel foam's low thermal conductivity, or high vibration absorption capability in the development of new applications for the material.

Existing analytical models for the homogenization of steel foam provide basic bounds on the behavior, and microstructural computational models show promise as a tool to expand experimental materials characterization and understanding. Further, continuum level plasticity models appropriate for metallic foams have been formulated.

Steel foam provides a unique opportunity for steel to fill a greater portion of the potential design space. Introducing density as a design variable increases designer freedom significantly. Further research involving more inclusive material tests, models of foams produced by more manufacturing methods, and structural-scale demonstrations of steel foams will fill existing gaps in knowledge and allow adoption of its use as a structural material. 


\section{Acknowledgements}

This paper is based in part upon work supported by the National Science Foundation under Grant No.'s CMMI-1000334, 1000167, and 0970059. Any opinions, findings, and conclusions or recommendations expressed in this material are those of the authors and do not necessarily reflect the views of the National Science Foundation.

\section{References}

[1] Kremer K, Liszkiewicz A and Adkins J. Development of Steel Foam Materials and Structures. US DOE and AISI final report DE-FC36-97ID13554 performed by Fraunhofer USA

- Delaware Center for Manufacturing and Advanced Materials, Newark, DE; 2004.

[2] Banhart J, Seeliger H. Aluminium foam sandwich panels: Manufacture, metallurgy and applications, Advanced Engineering Materials, 2008; 10:793-802.

[3] Private Correspondence with Prof. Thomas Hipke from Fraunhofer Institute in Chemnitz; 2011

[4] Neugebauer R, Hipke T, Hohlfeld J, and Thümmler R. Metal foam as a combination of lightweight engineering and damping. Cellular Metals and Polymers 2004. edited by Singer RF, Koerner C, Alstaedt V, Muenstedt H. 2005; pp. 13-18.

[5] Lefebvre L, Banhart J, Dunand D. Porous Metals and Metallic Foams: Current Status and Recent Developments, Adv. Eng. Mater, 2008; 10:775-787.

[6] Cardoso E, Oliveira B. Study of the use of metallic foam in a vehicle for an energy economy racing circuit, Materialwissenschaft Und Werkstofftechnik, 2010; 41:257-264.

[7] Ashby M. Metal foams: a design guide, Butterworth-Heinemann, Boston; 2000. 
[8] Reisgen U, Olschok S, Longerich S. Laser beam welding of open-porous metallic foams for application in cooling structures of combined cycle power plants, Journal of Engineering for Gas Turbines and Power, May 2010; Vol. 132.

[9] Shirzadi A, Zhu Y, Bhadeshia H. Joining ceramics to metals using metallic foam, Materials Science and Engineering A, 2008; 496:501-506.

[10] Levine B. A new era in porous metals: Applications in orthopaedics, Advanced Engineering Materials, 2008; 10:788-792.

[11] Coquard R, Rochais D, Baillis D. Conductive and Radiative Heat Transfer in Ceramic and Metal Foams at Fire Temperatures - Contribution to the Special Issue "Materials in Fire" Guest Editor K. Ghazi Wakili, July 2010.

[12] Lu T, Chen C. Thermal transport and fire retardance properties of cellular aluminium alloys, Acta Materialia, 1999; 47:1469-1485.

[13] Gohler H, Lothman P, Waag U, Schneidereit H, Bernhard E. Manufacture and properties of hollow sphere structures in sound absorption applications, MIT Verlag Publishing, Cellular Metals and Metal Foaming Technology (Germany) also known as MetFoam 2001; pp.391-396.

[14] Bao H, Han B. Transmission loss of metallic foams for the local resonance, in: 3rd International Conference on Bioinformatics and Biomedical Engineering, iCBBE 2009. [15] Losito O, Barletta D, Dimiccoli V. A wide-frequency model of metal foam for shielding applications, IEEE Transactions on Electromagnetic Compatibility, 2010; 52:75-81.

[16] Xu S, Bourham M, Rabiei A. A novel ultra-light structure for radiation shielding, Materials and Design, 2010; 31:2140-2146. 

gray iron foam by powder metallurgical synthesis." Suplemento de la Revista Latinoamericana de Metalurgia y Materiales, 2009; S1(4):1435-1440.

[18] Park C and Nutt SR. "Anisotropy and strain localization in steel foam.” Materials Science and Engineering A, 2001a; A299:68-74.

[19] Park C and Nutt SR. "Strain rate sensitivity and defects in steel foam." Materials Science and Engineering A, 2002; A323:358-366.

[20] Park C and Nutt SR. "PM synthesis and properties of steel foams.” Materials Science and Engineering A, 2000; A288:111-118.

[21] Nishiyabu K, Matsuzaki S, and Tanaka S . "Effectiveness of micro porous metal metal components with functionally graded structures.” MetFoam 2005: 4th International Conference on Porous Metals and Metal Foaming Technology. Japan Institute of Metals (JIMIC-4), 2005; 21-23 September 2005, Kyoto, Japan. p.325-328.

[22] Rabiei A and Vendra L J. “A comparison of composite metal foam's properties and other comparable metal foams." Materials Letters, 2009; 63:533-536.

[23] Friedl O, Motz C, Peterlik H, Puchegger S, Reger N, and Pippan R. "Experimental investigation of mechanical properties of metallic hollow sphere structures." Metallurgical and Materials Transactions B, 2007; 39(1):135-146.

[24] Brown JA, Vendra LJ, and Rabiei A. "Bending properties of Al-steel and steel-steel composite metal foams.” Metallurgical and Materials Transactions A. Online:1 July 2010. [25] Neville B P and Rabiei A. "Composite metal foams processed through powder metallurgy." Materials and Design, 2008; 29:388-396. 

investigation of mechanical properties of metallic hollow sphere structures." Metallurgical and Materials Transactions B, 2007; 39(1):135-146.

[27] Daxner T, Tomas R W, and Bitsche R D. "Mechanics of semi-expanded hollow sphere foams." MetFoam 2007: Proceedings of the 5th International Conference on Porous Metals and Metallic Foams. 5-7 September 2007, Montreal, Canada, 2007; p.169-172.

[28] Hyun S-K, Park J-S, Tane M, and Nakajima H. "Fabrication of lotus-type porous metals by continuous zone melting and continuous casting techniques.” MetFoam 2005: 4th International Conference on Porous Metals and Metal Foaming Technology. Japan Institute of Metals (JIMIC4), 2005; 21-23 September 2005, Kyoto, Japan.

[29] Ikeda T, Aoki T, and Nakajima H. "Fabrication of lotus-type porous stainless steel by continuous zone melting technique and mechanical property." Metallurgical and Materials Transactions A, 2007; 36A:77-86.

[30] Verdooren A, Chan HM, Grenestedt JL, Harmer MP, and Caram HS. "Fabrication of low density ferrous metallic foams by reduction of ceramic foam precursors." Journal of the Materials Science, 2005; 40:4333-4339.

[31] Verdooren A, Chan HM, Grenestedt JL, Harmer MP, and Caram HS. "Fabrication of low density ferrous metallic foams by reduction of chemically bonded ceramic foams." Journal of the American Ceramic Society, 2005 89(10):3101-3106.

[32] Adler J, Standke G, and Stephani G. "Sintered open-celled metal foams made by replication method - manufacturing and properties on example of 316L stainless steel foams." Proceedings of the Symposium on Cellular Metals and Polymers (CMaP). Deutsche Forschungsgemeinschaft (DFG), 12-14 October 2004, Fürth, Germany, 2004; p.89-92. 
production, parameters, characterisation." Proceedings of the Symposium on Cellular Metals and Polymers (CMaP). Deutsche Forschungsgemeinschaft (DFG), 12-14 October 2004, Fürth, Germany, 2004.

[34] Weise J, Beltrame Derner Silva G, and Salk N. "Production and properties of syntactic steel and iron foams with micro glass bubbles.", 2010; (unknown)

[35] Tuchinsky L. "Novel fabrication technology for metal foams.” Journal of Advanced Materials. 2005; 37(3):60-65.

[36] Lee B-K, Jeon I, Kang K-J. “Compressive characteristics of WBK truss cores.” MetFoam 2007: Proceedings of the 5th International Conference on Porous Metals and Metallic Foams. 5-7 September 2007, Montreal, Canada, 2007; pp.177-180.

[37] Kostornov A G, Kirichenko O V, Brodnikovskii N P, Guslienko Y A, and Klimenko V N. "High-porous materials made from alloy steel fibers: production, structure, and mechanical properties.” Powder Metallurgy and Metal Ceramics. 2008; 47(5-6):295-298.

[38] Ashby M F, Evans A G, Fleck N A, Gibson L J, Hutchinson J W, and Wadley H N G. Metal Foams: A Design Guide. Butterworth Hamilton, 2000.

[39] Fathy A, Ahmed A, and Morgan H. "Characterization and optimization of steel foam produced by slip casting process." MetFoam 2007: Proceedings of the 5th International Conference on Porous Metals and Metallic Foams. 5-7 September 2007, Montreal, Canada, 2007; p.161-164.

[40] Fazekas A, Dendievel R, Salvo L, and Brechet Y. "Effect of microstructural topology upon the stiffness and strength of 2D cellular structures." International Journal of Mechanical Sciences, 2002; 44:2047-2066. 
[41] Andrews E W, Gioux G, Onck P, and Gibson L J. "Size effects in ductile cellular solids.

Part II: experimental results.” International Journal of Mechanical Sciences. 2001; 43:701-713.

[42] Kujime T, Hyun S-K, and Nakajima H. "Mechanical properties of lotus-type porous carbon steel by continuous zone melting." MetFoam 2005: 4th International Conference on Porous Metals and Metal Foaming Technology. Japan Institute of Metals (JIMIC-4), 21-23 September 2005, Kyoto, Japan. 2005; p.525-528.

[43] Lim T-J, Smith B, and McDowell D L. "Behavior of a random hollow sphere metal foam." Acta Materiala, 2002; 50:2867-2879.

[44] Khayargoli P, Loya V, Lefebvre L P, and Medraj M. "The impact of microstructure on the permeability of metal foams.” CSME 2004 Forum. 2004; pp.220-228.

[45] Tang H P, Zhu J L, Wang J Y, Ge Y, and Li C. "Sound absorption characters of metal fibrous porous material.” MetFoam 2007: Proceedings of the 5th International Conference on Porous Metals and Metallic Foams. 5-7 September 2007, Montreal, Canada, 2007; pp.181-184. [46] Zhao C Y, Lu T J, Hodson H P, and Jackson J D. "The temperature dependence of effective thermal conductivity of open-celled steel alloy foams." Materials Science and Engineering A, 2004; 267:123-131.

[47] Nakajima H, Ikeda T, and Hyun S K. "Fabrication of lotus-type porous metals and physical properties.” Cellular Metals: Manufacture, Properties, Applications: 3rd International Conference on Cellular Metals and Metal Foaming Technology, Metall Innovation Technologie MIT, 23-25 June 2003, Berlin, Germany, 2003; p.191-202.

[48] Shapovalov V and Boyko L. "Gasar - a new class of porous materials: syntheses, structure, properties, and potential applications." Banhart J, Ashby M F, and Fleck N A, ed. (2001). 2nd 
International Conference on Cellular Metals and Metal Foaming Technology, Metall Innovation Technologie MIT, 18-20 June 2001, Bremen, Germany, 2001; pp.201-208.

[49] Krupp U, Aegerter J, Ohrndorf A, Guillen T, Danninger A, Hipke T, Hohlfeld J, and Reinfired M. "Development of a standard for compression testing of cellular materials." MetFoam 2007: Proceedings of the 5th International Conference on Porous Metals and Metallic Foams. 5-7 September 2007, Montreal, Canada, 2007; 407-410.

[50] Kwon Y W, Cooke R E, and Park C. "Representative unit-cell models for open-cell metal foams with or without elastic filler." Materials Science and Engineering A, 2002; 343:63-70. [51] Kepets M, Lu T J, and Dowling A P. "Modeling of the role of defects in sintered FeCrAlY foams." Acta Mech Sin, 2007; 23:511-529.

[52] Gasser S, Paun F, and Bechet Y. "Finite elements computation for the elastic properties of a regular stacking of hollow spheres." Materials Science and Engineering A, 2004; 379:240-244. [53] Fallet A, Lhuissier P, Salvo L, and Brechet Y. "Mechanical behaviour of metallic hollow spheres foam."Advanced Engineering Materials, 2008; 10(9):858-862.

[54] Sanders W S and Gibson L J. "Mechanics of hollow sphere foams." Materials Science and Engineering A, 2002; 347:70-85.

[55] Karagiozova D, Yu T X, and Gao Z Y. "Stress-strain relationship for metal hollow sphere materials as a function of their relative density." Transactions of the ASME, 2007; 74:898-907. [56] Ochsner A. "Numerical Simulation of Thermal and Mechanical Properties of Sintered Perforated Hollow Sphere Structures (PHSS).” AIP Conference Proceedings. 2009; 1177:16-30. [57] Speich M, Rimkus W, Merkel M, and Öchsner A. "Large deformation of metallic hollow spheres." Materials Science Forum, 2009; 623:105-117. 
[58] Kari S, Berger H, Rodriguez-Ramos R, and Gabbert U. "Computational evaluation of

effective material properties of composites reinforced by randomly distributed spherical particles." Composite Structures, 2007; 77:223-231.

[59] Karagiozova D, Yu T X, and Gao Z Y. "Modelling of MHS cellular solid in large strains." International Journal of Mechanical Sciences, 2006; 48:1273-1286

[60] Franeck J and Landgraf G. "Determination of linear and non-linear mechanical properties of sintered hollow-sphere structures.” Proceedings of the Symposium on Cellular Metals and Polymers (CMaP). Deutsche Forschungsgemeinschaft (DFG), 12-14 October 2004, Fürth, Germany, 2004; pp.139-142.

[61] Gao Z Y, Yu T X, and Karagiozova D. "Finite element simulations on the mechanical properties of MHS materials.”Acta Mech Sin, 2007; 23:65-75.

[62] Gibson MF and Ashby LJ. Cellular Solids: Structure \& Properties. Oxfordshire Press, 1997. [63] Gauthier M. "Structure and properties of open-cell 316L stainless steel foams produced by a powder metallurgy-based process.” MetFoam 2007: Proceedings of the 5th International Conference on Porous Metals and Metallic Foams. 5-7 September 2007, Montreal, Canada, 2007; pp.149-152.

[64] Sanders W S. "Mechanical behavior of closed-cell and hollow-sphere metallic foams." Massachusetts Institute of Technology (D.Sc. thesis). Advisor Gibson L J. 2002.

[65] Sanders W S and Gibson L J. "Mechanics of BCC and FCC hollow-sphere foams." Materials Science and Engineering A, 2002; 352:150-161.

[66] Khan A, Continuum theory of plasticity. Wiley, New York; 1995.

[67] Miller RE. A continuum plasticity model for the constitutive and indentation behaviour of foamed metals, International Journal of Mechanical Sciences, 2000; 42:729-754. 